\title{
Second Language Learners Making Video in Three Contexts
}

\author{
KELLEEN TOOHEY \\ Simon Fraser University \\ DIANE DAGENAIS \\ Simon Fraser University \\ ELIZABETH SCHULZE \\ Pacific Cinématheque
}

\begin{abstract}
We describe videomaking projects in Canada, India, and Mexico in which second language learners were asked to show the children in the other countries what their lives were like. We consider how this form of expression might contribute to second language learning and allow children to make use of in and out-of-school resources. We also raise questions about the affordances and constraints of the videomaking process and explore how teachers might approach such multimodal literacy activities with children.
\end{abstract}

Hello. My name is R. It's Halloween and I'm dressed up as, I don't know if you've heard of him, but I'm Joe Jonas of the Jonas Brothers.

(from video made by Canadian children for Tibetan children in India, 2009)

Hello. My name is M. and I'm in Class 8. I like to listen to the songs and I like also gossip.

And I like to eat chocolate. And my favourite singers are Jonas Brothers and Miley.

(from video made by Tibetan children in India for Canadian children, 2009).

\section{Introduction}

The education of children who speak minority languages is a global concern. Recently, Gutiérrez, Zepeda and Castro (2010) observe lower overall school achievement in minority language-speaking compared to English-speaking children in the United States, and argue that "what is effective pedagogy and practice for [minority languagespeaking children] remains an unanswered empirical question" (p. 335). Such gaps have been noted not only in the United States, but also in Australia, Britain, Canada and France (Australia Council for Educational Research, 1997; Bourne, 2007; Gunderson, 2007; Toohey \& Derwing, 2008; Vallet \& Caille, 2000). Even though child learners quickly develop oral interactional skills in their second languages ${ }^{\mathrm{i}}$ (L2s), educational researchers of widely varying philosophical positions, using diverse research approaches, agree that school literacy activities present the greatest challenge for child L2 learners, especially after about Grade 3 (Alvermann \& Phelps, 1998; Carrasquillo, Kucer \& 
Abrams, 2004; Strickland \& Alvermann, 2004). During the intermediate grades (4-7), literacy difficulties become apparent for many learners, but they are even more highly visible with respect to L2 learners (August \& Shanahan, 2006; Strickland \& Alvermann, 2004) and persist throughout and beyond school (Grayson, 2008). Many scholars have noted the paucity of research on L2 learners' literacy development and have called for research to examine how pedagogical interventions affect their literacy learning (Bernhardt, 2000; Carrasquillo, Kucer \& Abrams, 2004; Hawkins, 2005). Hawkins (2004) observes that the field lacks "a close identification of the multiple forms of language and literacy practices in classrooms, a comprehensive look at how ELLs (English language learners) do and/or don't engage in these practices, and what successful scaffolding and supportive environments might look like" (p. 14, our parenthesis).

Empirical research about L2 literacy difficulties often assumes a definition of literacy as meaning-making with written language. However, in addition to written language, meaning-making with music, sound, image, gesture, space, moving images, and blends of these modes surround children of the $21^{\text {st }}$ century, and many argue that schools in the digital age should help all students (not only L2 learners) develop multimodal literacies (e.g., Carrington \& Marsh, 2005; Coiro, Knobel, Lankshear, \& Leu, 2008; Early \& Marshall, 2008; Gee, 2004; Hague \& Williamson, 2009; Kress, 2000, 2003; Mills, 2010a, 2010b; Rhodes \& Robnolt, 2009; Sanford \& Madill, 2008). Many also argues that involving learners in creating multimodal texts offers possibilities for personal expression and collective representation in more sophisticated ways than learners are able to produce in only written language (e.g., Brass, 2008; deBruin-Parecki \& Klein, 2003; Edutopia, 2010; Lopéz-Gopar, 2007). As Hull and Stornaiuolo (2010) remind us, "Of course, all children and youth require $21^{\text {st }}$-century tools and practices, and opportunities, as well as powerful versions of literacy... to participate most agentively in their social and economic futures" (p. 84).

Despite encouragement from educational researchers, and although many schooling authorities advocate the teaching of multimodal literacies, many have noted that instruction in multi-media technologies is infrequent in L2 classrooms (Carrington \& Marsh, 2005; Lotherington, 2009; Stein, 2004). Possible reasons for the infrequency might include insufficient technological access, technical support, curricular time, educator professional development in the practical and conceptual processes of multimodal literacies, and administrative support at the school and district level. In our work with L2 learners in schools in Canada, we have been interested in supporting teachers to explore multimodal literacies as they use multimedia technologies with their students.

In this paper, we describe our experiences in videomaking projects we sponsored in Canada, India, and Mexico so that children could show children in the other site "what their lives were like" through video ${ }^{\text {ii }}$. The children were English language learners between 9 and 12 years of age. The Canadian children were almost all first language speakers of Punjabi and were enrolled in English-medium public schools; the Mexican children all had Spanish as their first language and attended bilingual English and Zapotec lessons at a community library; and the Tibetan children spoke both Tibetan and Hindi (with varying degrees of fluency) and were enrolled in a boarding school in northern India where they received instruction in Tibetan and English. In this primarily 
descriptive paper, we present three of the products children created, raise questions that arise from the videomaking process and discuss how researchers and teachers might approach videomaking with children. We are interested in the affordances and constraints of videomaking---how this form of creative expression might contribute to L2 learning. We are also interested in how videomaking allows children to make use of in and out-ofschool physical and social resources. These descriptions of videomaking projects raise questions that might stimulate discussion about and enthusiasm for multimodal meaningmaking with L2 learners. We begin with a brief background sketch of recent literacy theory and research and how multimodality has been approached in studies of L2 learning.

\section{Literacy}

\section{Developments in Literacy Theory and Research}

Literacy theory and research has undergone significant shifts over the past thirty years. From a conceptualization of literacy as a portable unitary skill to seeing literacy as a situated social practice, literacy theorists have increasingly emphasized the complexity of how literacy is accomplished in particular contexts. Contemporary literacy theorists allied with the "New Literacy Studies" (NLS) see literacy as a "repertoire of changing practices for communicating purposely in multiple social and cultural contexts" (Mills, 2010 b, p. 247) and highlight the many contexts in which literacy practices develop, and the various forms literacy takes. For NLS theorists, literacy is not a particular skill or a set of skills acquired by individuals and thereafter universally applicable, but is, instead, sets of practices that take place in particular environments, for different reasons, using varying tools, and involving varying persons, texts, and social relations (Barton \& Hamilton, 1998; Gee, 2004; Street, 1984, 1995, 1998). As Rowsell (2008) puts it, "NLS calls into question the notion of a singular model of literacy and offers the notion of literacies" (n.p.). Much of the focus of early ethnographic work in NLS was documentation of the varieties of ways literacy practices were enacted in various historical, geographic, economic, and political contexts, so as to yield comparative data that would make important aspects of those practices salient. Heath's (1983) early and ground-breaking study on literacy practices in three communities in Appalachia highlights how school literacy practices were sometimes in direct contrast with community practices. Heath and many others have subsequently argued that literacy researchers should document community literacy practices so as to build on children's outside-school competencies in school (Heath \& McLaughlin, 1993; Hull \& Schultz, 2002; Hull \& Nelson, 2005; Marsh, 2006; Pahl \& Rowsell, 2006).

A corollary of the argument that school instruction should draw from "the practices [students] bring to student life from other domains of their lives" (Edwards, Ivanic, \& Mannion, 2009, p. 483) concerns L2 learners, with research demonstrating that when such learners are able to maintain ties with their home languages and cultures, they are better able to benefit from school instruction: that is, their school achievement is higher and they demonstrate higher self esteem and have higher educational and occupational aspirations (Cummins, 2009; Portes \& Rumbaut, 2001). Thus, increasingly, researchers argue that attention to the first language, as well as the second, is important if learners are to benefit maximally from school instruction. Means to maintain ties with home languages and cultures are not of high frequency in Canadian schools at least, but there 
have been some projects that attempt to do just this. Cummins and Early (2011), for example, engaged with teachers in multilingual schools in Vancouver, Toronto, and Montreal (www.multiliteracies.ca) to support multilingual practices with students, precisely because of the conviction that providing links to home languages enhances L2 learning.

\section{Multimodal Literacies at School}

Publication of the "Pedagogies of Multiliteracies" manifesto in the Harvard Educational Review in 1996 marked a watershed in conceptualizations of literacy. Those responsible for its articulation, the New London Group, despite differences in their national, political, and social affiliations, agreed on two arguments: "The first argument engages with the multiplicity of communications channels and media; the second with the increasing salience of cultural and linguistic diversity" (Cope \& Kalantzis, 2000, p. 5). Like many others before 1996 and subsequently, the New London Group argue that the increasing presence of digital media, in which meanings are communicated through text, but also through music, sound, image, and moving images, had become very important in the lives of children and adults globally. As Mills (2010a) observes, theorists internationally argue that digital technologies "have decisively changed antiquated notions of language, curriculum and literacy research. Texts are increasingly multimodal, that is, they combine visual, audio, linguistic, gestural, and spatial modes to convey meaning in a richer way" (p. 15). Similarly, Poyntz (2009) reminds us that "Beginning in infancy, young people now grow up learning the language of mass media through a constant diet of screen images, audio messages, and text-based communication" (p. 369). Like Luke (2002), he saw these complex mediascapes as a kind of "curriculum", "a series of elements (such as characters, plots and textual forms)' out of which young people (and others) produce scripts of 'imagined lives' (Appadurai 1996, 35-36)" (Poyntz, p. 369).

Several studies have suggested that struggling students (especially youth in secondary schools) engage powerfully with multimodal literacies, and that such activity might strengthen their commitment to and engagement in schooling (Kist, 2005; Rogers, 2009; Rogers, Winters, LaMonde, \& Perry, in press). Hull and Zacher (2004) and Hull (2007), for example, described an out-of-school program in which underachieving readers created remarkable multimedia products to represent their knowledge and learning. Hull (2005) argues that the participants' digital stories (which included print, music, and images) were a different kind of meaning making exercise from simply starting with words and adding images, music or videos. Rather, she suggests that the digital tools allowed children and youth to think about and represent meaning more wholistically, as they presented powerful stories that are too often unheard, as print literacies had not been easy for these participants to appropriate. With respect to video production, Poyntz (2006) similarly argues that analyses by teachers and peers of student work offers "opportunities furthering a sense of agency and reflexivity among youth" (p. 158).

Rogers and Schofield (2005) report a school-based multiple literacies alternative program for struggling learners that invited them to use autobiography as a genre to extend their literate repertoires. The very promising results of the multimedia projects led the authors to claim, 
If we reconceptualize literacy as a set of imaginative and material social practices... the assumed dichotomy of in- and out-of-school literacies comes into question. We work with the literacies of youth by finding ways of valuing their reading and writing across school boundaries, or within the interstices of those boundaries, and extending their narratives to include wider and wider horizons of experience... Expressing themselves through multimedia narratives provides an opportunity for students to display, reflect on, and reinterpret those identities and experiences. (p. 216)

Similarly, Gutiérrez (2008) describes a summer project where poor Latino students who hope to go to college, were brought to campus in the summertime initially to produce multimodal autobiographies, but later were challenged to place those personal stories in their historical, political, and economic contexts. In this way, their reflections could lead to understanding why they may encounter difficulties in their paths to university, make plans for addressing such obstacles, and also lead to what Gutierrez calls "social dreaming" about just futures (p. 157).

While there has been research examining the teaching of multimodal literacies to L2 students (Ajayi, 2008, 2009; Lotherington, 2007, 2009; Skinner \& Hagood, 2008; Ware, 2008; Willis \& Harris, 2000), there have been only a few studies specifically concerned with videomaking with L2 learners. Some studies report using video with L2 learners to provide authentic language samples and to allow learners to become aware of and correct their errors (Gromik, 2009; Hanson-Smith, 2007; Hofer \& Owings-Swan, 2005; Levy \& Kennedy, 2004). Li (2010) recently describes videomaking with adult L2 students. However, we have not seen other studies of videomaking with L2 learners the age of the children with whom we work.

We have informally observed in our projects that videomaking seemed to enhance L2 learners' language learning, involve them in print literate tasks, and could engage them powerfully in discussions with peers about aspects of composition, storytelling, language usage, and filmic techniques (and their effects on viewers). We have hypothesized that video production's incorporation of written, visual, and aural modalities in the planning and script-writing phases (pre-production) offers students practice opportunities and can offer teachers insight into students' strengths and weaknesses in literacy practices. Seemingly, the promise of creative production during filming and sound recording (production) can also provide motivation and incentive for students to challenge themselves and to work through personal, group, and technical challenges. The post-production phase, in which students must work together to negotiate story and editing choices, actively consider audience perspectives, develop audio soundscapes, and integrate video, audio, and story, seems to offer much with respect to high-level literacy learning. Although our current ongoing research (not reported here but see Section 5.5) is concerned with developing ways to analyze children's video products and their production, we undertook the projects reported here because our previous experience suggested some of the affordances of videomaking with L2 learners.

\section{The Process}

Our previous research with child L2 learners in Canada produced inventories of outside-school multilingual literacy practices in communities in metropolitan Vancouver (Dagenais, 2008; Dagenais \& Moore, 2008; Smythe \& Toohey, 2009a, 2009b; Marshall 
\& Toohey, 2010). Children in these communities were highly engaged in a variety of sometimes multilingual literate activities outside school, as well as interested and involved in digital technologies (e.g., video games, Internet social networking); we also noted their blending of media (including print) in these activities. We worked with teachers and L2 learners in a variety of multimodal projects: photography, podcasts, multimodal storybooks, viewing multilingual videos and making videos related to multilingualism. All of these projects were characterized by high engagement on the part of the children and blended multiple print literacy activities with the tools made available to the children. Videomaking, as we have already discussed above, (in activities like script writing, storyboarding, and oral rehearsal) seemed particularly powerful in providing opportunities for learners to enhance their spoken and written L2 literacies, and it allowed them to make use of their community language resources and repertoires, resources they are rarely able to display or build upon in school. In videomaking activities, children were enthusiastic about learning the technology and highly engaged in completing L2 print literacy practices in order to produce the videos.

Based on these observations and the discovery that student teachers at our university were undertaking their first practicum experience of six weeks in India, Author 1 sponsored an exchange of videos with the Tibetan-speaking children in India with whom our student teachers worked, and the Punjabi-speaking children in Canada with whom she had previously worked. In 2010, the first author Kelleen Toohey and the second author Diane Dagenais extended the project to include Spanish-speaking children in Mexico, again somewhat opportunistically as part of an exploratory field-based study, as our university had student teachers going to Mexico to work with these children. Subsequently Kelleen visited and observed the children and student teachers in India while they were making their videos and Diane did the same in Mexico. The children in India had received Tibetan-medium instruction from kindergarten to Grade 5 and English immersion instruction from Grades 5 to 12. The videomaking activities reported on here took place after school with students enrolled in Grades 6 to 8. The Mexican children were between 8 and 12 years old and they attended a Spanish language elementary school. They worked on the video project during English and Zapotecan lessons at a local community library after school. The children in Canada attended a suburban elementary school where they received instruction in English and they worked on the video production during school hours.

Before the start of the teaching internships, we had time only to provide a short tutorial in camera functioning and video editing for the student teachers in a workshop led by the third author Elizabeth Schulze from Pacific Cinémathèque (a non-profit film society in Vancouver that offers, among many other services, workshops to children and youth in video/movie making). None of them had had formal training in visual language, photographic composition, or professional development in strategies for teaching with this technology. In their very brief orientation, they were introduced to planning, shooting and editing video and were shown snippets of previously produced children's videos (from the earlier project). The student teachers were provided video cameras, tripods, and MacBooks with the video editing software iMovie installed (we found version 6.0.3 easier to navigate than more current versions), and subsequently, they left the university to go on their practica. 


\section{The Videos}

Video \#1: Hello from Canada

Prompted by their classroom teacher, students from one of the Canadian schools produced a "preliminary" video as a prelude to the upcoming, more formal video that was the project's intended deliverable. As several of the children in this school had attended video camps in Kelleen's previous projects, they felt comfortable putting together a "quick and dirty" version to introduce themselves to the other students. The video was produced and packaged in a DVD, with an introductory menu screen that displays a slideshow of different in-school photos, and titled "Hello from Canada".

As the video begins, a short sequence of shots pans across the exterior and interior entrance to the school and the classroom in which the video club met each week. Initial dialogue comes from the teacher, who sits in the classroom amongst a group of unseen but clearly audible giggling children. She says hello to "everyone," speaking to her imagined audience, and explains the giggling as students who are "a little bit nervous about our first, sort of, welcoming tape." She then encourages the now-visible giggling children to introduce themselves, which eventually they do, despite occasional incidents of self-consciousness and visible nervousness. As the students speak in English, giving their names, grades, school, and hobbies, they are prompted occasionally to share their backgrounds and current life experiences for their imagined counterparts in India. Interspersed with the students' self-introductions are another teacher's and a student teacher's introductions, both given in Punjabi (a language the Tibetan children would not be unfamiliar with, as they are enthusiastic viewers of Bollywood movies, which are sometimes in Punjabi; as well, many Punjabis visit the students' northern India town as tourists).

The camera, accompanied by narrating students, then tours their classroom space, pointing out various items, several of which connect to international, multilingual themes---in one case a picture of the Golden Temple in Amritsar ${ }^{\text {iii }}$ is pointed out specifically. Two girls from the early introductions speak confidently, guiding the tour. Specifically finding common points of linguistic and cultural reference (i.e., the Golden Temple and a diagram of the word "Welcome" written in multiple languages, in which they point out Hindi and Punjabi) the students look into the camera lens, speaking to and looking at an imagined viewer until the video abruptly ends.

The children intended this video to be only an introduction to themselves and their school to the children in the other sites, and they worked hard on getting footage for their 'real' video. However, they didn't know it was a school policy to scrub computers in the school's computer lab during school breaks and all their raw footage was erased during the Christmas vacation,. Despite their disappointment and upset, the children then decided to present a digital slide show with music that they could share with the other children.

\section{Video \#2: Introduction to Our School}

The Tibetan video runs 39 minutes and owing to a lack of time and limited access to computer equipment in India, it was edited by the student teachers upon their return to Canada. The video begins with an opening slide displaying Tibetan prayer flags, a fullclass "Hello" in Tibetan, and on-camera individual introductions to all participating students. Like the Canadian students' introductory video, one at a time, before a still 
camera overlooking a concrete schoolyard, children step into place in front of the camera and state their names, grades and their "likes" or career ambitions. All the girls proceed first, with the boys appearing after, some giggling occasionally during their moments oncamera. Students' "likes" include international cultural phenomena, from the Jonas Brothers and Rihanna to Michael Jackson, and they speak of diverse career aspirations and hobbies. In this section, the students appear to be reproducing the other children's first video, and perhaps other videos they have seen in which people are individually introduced.

However, following this 5-minute scene is a hosted sequence in which three students describe, then demonstrate (first in Tibetan and subsequently in English) the process of Tibetan dialectics in which students undertake a physicalized form of debate used by some Tibetan Buddhists. The two hosts, a young boy and girl from the initial introductions, explain the activity. The boy speaks in Tibetan, followed by the girl narrating the following script:

5:32 Good morning everyone. What is dialectic? It is a process of debating where... everything in your mind... while debating. Actually, dialectic makes our muscular cells refreshed. It is also developing intellectually which makes you wise.... We do not do dialectic on Wednesday because this day is very special for our Dalai Lama so this day we pray.... We can have dialectic in everything. The dialectic ensures the people to notice everything and to have knowledge in our hearts. ${ }^{\text {iv }}$

Choosing a sample debate topic, the host leaves the frame while one student crouches down. Another stands and speaks in Tibetan while gesturing with his arms, rhythmically leaning and clapping towards his opponent at the end of each sentence. Our female host returns and looks into the camera, explaining quickly in English that "they are doing this kind of acting because... to inviting the answer." The standing Tibetan-speaking student proceeds again, gesturing and clapping after each sentence, and then suddenly alters his gesture to sweep one arm away from his seated opponent. Our host comes back in front of the camera, stating in English that "this acting shows that the person who giving an answer, give wrong answer." The initial gesturing and clapping continues, completed with a final, dramatic clap and a stomp. Again, our host returns to share that "this acting shows that now he accepts his mistook [mistake]." With their demonstration and explanation complete, the host states that all students from Classes 4-10 undertake this activity after breakfast every day except Wednesday, whereupon the shot ends and we see a roving camera capturing a whole schoolyard of students engaged in the same activity. This segment of the children's video is clearly distinguished from the rest of the video: the English speech the girl has memorized is lengthy, and the meanings she is trying to convey are complex. We do not know how the decision was made to represent Buddhist dialectic practice. The explanation clearly stretched the narrator's knowledge of English; however, despite these difficulties, the children chose to show the dialectics in some detail.

Another female student then appears, becoming one of several subsequent hosts, welcoming viewers to an extended tour around their schoolrooms, grounds, library, dormitories, shrine, and terraces. As in the dialectics segment, students describe their surroundings while looking and speaking directly to the camera, speaking first in Tibetan 
and subsequently in English. Students are both acting as guides and operating the camera. Special attention is paid to select details: daily routines and schedules, American "Sweet Valley High" and "Two of a Kind" books in the library, and Buddhist rituals and objects explained in detail in the school's shrine. These explanatory scenes are interspersed with brief moments in which the broader landscape is revealed in shots out windows and from balconies, lit in amber tones as the afternoon light covers the trees and buildings of the school's neighborhood. The video finishes with two final scenes: an English-language song (by the American band "Green Day") sung very enthusiastically by the boys in the after-school video program, accompanied by Student Teachers playing guitars, and a skit in which a narrator tells the camera that they will show what happens when a teacher leaves the classroom. A boy and a girl are featured, and after a student teacher leaves the room, the boy writes on the board, jumps around noisily and sits in the teacher's chair. The girl sleeps on her desk. The narrator comes back, saying, "When the teacher is not there, P. does funny things and D. sleeps. I think it is the same in Canada school." The skit abruptly ends to be followed by the video's rolling credit sequence, which plays to the Green Day version of the previously-played song.

\section{Video \#3: Biblioteca Comunitaria - Community Library}

In a series of brainstorming sessions led by the library director, the Mexican children made decisions as a group about what to film, where to shoot, and who to feature in their video. They produced the storyboard and the scripts for the video in small groups under the guidance of the student teachers. However, because their parents were concerned that they might break the video equipment, the children were not allowed to manipulate the cameras, so while the children provided direction, the student teachers did all the actual shooting and editing. Their video, which lasts 21 minutes, provides a tour of various locations in and around the community library. The first clip opens with a wide shot of the children sitting on a carpet in a circle at the community library. They draw in notebooks while the student teachers kneel next to them to talk in English and Spanish. Bursts of laughter punctuate the sound of the children and adults speaking both languages. A close-up shot shows their drawings with words in Spanish or English that the children have hand-written below. In the following clip, the children take turns to sit on a chair, look shyly at the camera and introduce themselves individually to the viewers in English or in Spanish. Some describe their family and a few show pictures of them while they talk. Whereas most have memorized their lines, a couple of children read their scripts. The next clip shows two boys standing in front of a colourful mural painted along the wall of a street nearby. The mural announces an upcoming parade for the Day of the Dead and the boys explain in Spanish how this holiday is celebrated in their families. The following clip features the children running into the local schoolyard where two girls point to the windows of their classroom and the computer lab, saying in English "This is my classroom, I like it". As the camera pans the schoolyard and we see a group of children playing basketball, the girls tell the viewers in English that the children like basketball. The next clip features three boys who introduce the local church in English saying "Welcome to church Catholic. We are Catholic". They provide a tour of the interior as they explain in Spanish when Masses are held, who the statues of saints represent, and why the statue of Jesus is the most important of all. The tour ends with the boys introducing the priest sitting in his office and the bell-ringer as he rings the church 
bell. In the next clip, three girls standing in the shade of a tree provide a commentary on the games children play in the local university sports field as the camera pans the area, providing a view of the arid landscape and the mountains in the background. The following three clips are short shots of the children engaged in a foot race, a soccerbaseball game, and skipping in the sports field. Mexican music has been added as background sound to this segment of the video. The next clip provides a view from behind of the children walking as a group with the student teachers and the library director along a side street toward the community library. The final clip shows the children painting a mural on the wall of the community library with more Mexican music featured as background sound.

\section{Discussion}

Like many teachers and researchers who work with youth and video, we viewed these videos as cause for celebration, as did the children and their teachers. The student teachers reported to us that the children's engagement, enjoyment, and effort in making the videos were evident, and they represented somewhat different kind of texts being created and validated by the school (or at least one teacher in one school and student teachers in the other). However, it is unclear to us how much pedagogical follow-up occurred across sites beyond showing the videos to children in the other sites (which we observed in only a couple of cases). As we have indicated elsewhere (Marshall \& Toohey, 2010), we had a sense that the videos were seen as a "special project" that was not necessarily integrated with other learning activities or the school curriculum.

Poyntz (2006) makes the argument that when educators approach youth-produced text as self-expression, but self-expression grounded in particular social and political formations, and when they engage in dialogue about these matters with their students, opportunities abound for young people to develop a sense of agency and reflexivity. Because our visits to the external sites were brief, we did not have the opportunity to talk with most of the student producers after the videomaking process, but we were able to interview the student teachers upon their return from their practica and they provided contextual information that was helpful to our search for means to understand the video products we described above. The following sections explain factors we found important in coming to understand more about video products and process.

\section{Production Means and Modes}

While there are a number of possible ways to undertake video production with children, as we have seen in the three videos described here, means and modes of production can have an impact on both process and product. While technical concerns are not deterministically connected to students' video products, the videos we examined point out that a number of logistical details must be incorporated into educators' planning for and undertaking of video production, all of which play an active role in the resulting video projects. These include a wide array of factors, including the amount of instructional and work time allotted for the project (always more than is planned), the amount of space provided to students during the process, the degree of control children have over the process, and the techniques children are instructed in or have available to them. While space does not permit the full exploration of these relationships, they must be considered at all phases of the planning, production, and assessment of the video 
productions.

Technical capabilities (from equipment access to technical training and support) result in a wide range of project implications: the low number of computers in the Tibetan case made it difficult for many students to participate in the editing phase; parental concerns about potential damage to video equipment in the Mexican context made it impossible for the children to do the filming themselves; the poor level of security for student projects resulted in deletion of data for the Canadian school's second video; and the lack of access to external microphones resulted in unclear audio and dialogue recording in all cases. While the intimidating number and range of considerations may be daunting, an examination of such logistics before the project's initiation invites educators to consider how they may use equipment to facilitate the creation of effective and feasible video projects, and how they may make use of video tools in the development of multimodal literacies.

In our experience, in classroom environments where video projects are being considered or have already begun, technical concerns may override other creative choices and capabilities, and can become both discouraging and deterring for educators' willingness to undertake video or multimedia activities with their students. In situations like the Canadian students' second video, when technical "disasters" occur, educators can be technically unsure of how to proceed, and may even choose to abandon the video project altogether. As with any new activity, practice and repetition of videomaking helps to streamline the process and avoid common pitfalls and assure teachers that creative problem-solving is an inherent part of the process.

\section{Artistic, Textual and Sociocultural Properties}

With respect to the artistic aspects of the children's videos, we do not think that the video instructors extensively engaged students in development of a common visual language and film vocabulary. The videos (all composed in medium and long shots, with significant distance between the camera and subjects) appear to suggest that this topic was not explored. Shot in an unexamined and untrained style, as all the videos were, opportunities for engaging viewers with varieties of shots, angles, and other formal techniques, were missed, and though children were generally pleased with their productions, they might have found them even more pleasing had they had instruction in what various shots "mean" and can "mean".

Many observers have recognized that much of the content and form of child- and youth-produced videos derives from mainstream media, and that mainstream representations of reality sustain dominant power relations in society. Therefore, such critics might argue that child "ventriloquations" (Bakhtin, 1981) of such media have little to offer children in terms of encouraging artistic, textual or sociocultural originality, agency and self and collective representation. However, it is possible that ventriloquation is not an inevitable result of children's referencing of mainstream media. Poyntz (2009) argues that while youth-produced media often makes use of globalized media elements, their products are not mere replication, but instead are "linked to local concerns and forms of cultural expression, patterns and protocols of technological use and integration among different groups, as well as national concerns and regulatory frameworks (Appadurai 1996)" (p. 369). Dyson (1997) points out that children using the cultural symbols available to them from television in particular, and re-work those characters, 
events and discourse, in play and in writing. She further notes that as their peers and their teacher challenged, affirmed, and discussed children's writing, children's literacy practices developed significantly. The reworking of available cultural symbols in local cultural production has been recognized by many observers. Anthropologists Holland, Skinner, Lachiotte, and Cain (1998), for example, wrote about the development of identity and agency, noting that identities are cultural productions and that they are "improvised... from the cultural resources at hand" (p. 4). Despite the re-use of available cultural resources, Holland et al. note that in social activity, resources are changed, used in new ways and new activities.

The videos the children produced in our project certainly draw upon global and previously-used cultural resources to achieve their assignment: to tell each other what their lives were like (an identity-representing activity). The content and form of all the videos in many ways mimics the form and structure of previous films they had been exposed to: school tour videos, travel documentaries and possibly other video or films the students have seen, where a narrator moves about a space explaining what happens where. The children feature music and sports in their videos, and comfortably reference pop culture figures (i.e., the Jonas Brothers, Michael Jackson) alongside religious figures (i.e., the Dalai Lama, Jesus) of particular significance to their communities to represent their identities. While they are not necessarily reworking characters or roles as might be the case were a narrative video project undertaken, students' juxtaposition of various global and local figures evidence their ease in relating to and integrating diverse cultural elements in presenting themselves to one another.

One might observe that the use of two languages in some of the videos constitutes an "improvisation" (Holland et al., 1998, p. 4) on the part of the students in some sense (although the student teachers saw previous bilingual video camp-produced videos). The students' ongoing use of two languages throughout almost all the scenes in the Indian and Mexican videos, contributes somewhat to the videos' extended length. Perhaps prompted by their student teachers' expectations and the stated assignment requirements, the choice to include both languages created opportunities and logistical and conceptual challenges for these children. As suggested elsewhere (Dagenais, in press), the possibility of drawing on either of the languages in their repertoire enabled the children to have some choices and control over their learning process. Since bilingual practices were legitimized, those children who so desired were able to show viewers that they had attained a certain level of competence in English and/or demonstrate their linguistic and cultural knowledge in their first language. Those who chose to speak English could use gestures to make meaning or refer to a script or objects such as pictures and statues as support in communicating their message. These L2 learners were thus able to mobilize whatever linguistic, cultural, material, visual, and gestural resources were needed to convey what they wanted to their audience. In each bilingual scene, simultaneously with touring and speaking into the camera at their audience, students are seen to make intentional choices in on-camera dialogue content (what to point out and how to explain it), structuring (deciding on what to say, how much to say in each section of dialogue, and how fast to say it), and translation (varying somewhat due to L2 learners' spoken English). Producing the video bilingually, and taking on religious and other complex topics, students were challenged to find ways of conveying in English meanings and ideas that they might typically have heard exclusively in their first language. The children in the Canadian 
school did not produce their video bilingually (although they had produced bilingual videos at their video camps, and the difficulties around losing so much of their footage may have accounted for the almost exclusive use of English in their videos.) However, a teacher and a student teacher spoke in Punjabi and children pointed out the Hindi and Gurkmukhi script on a poster in their introductory video. In other videos these Canadian children have produced in the past, they have used exclusively Punjabi (with English subtitles) and exclusively English for some scenes and some speakers, and have involved discussions with one another about which language would be appropriate for which scenes and which characters. As we shall argue later, it may be that even more improvisations with cultural resources might have been encouraged through pedagogical moves on the part of the instructors.

We see in the videos common references and cultural symbols, from the Jonas Brothers to basketball. The children in all sites decided to include these references, whether to present themselves as globally au courant, or to find commonalities with viewers. In all three videos, we see decisions the children have made to situate themselves as part of a global "pre-teenhood", and possibly (though we cannot be certain) to acknowledge viewers' common interests. Another example of children surmising similarities is when one of the Tibetan narrators in their video's final skit says explicitly about student misbehaviour when teachers are out of the room, "I think it is the same in Canada school".

Children in each case also introduced topics and settings that they assumed would be new to the children in the other site. The Mexican children's video tour of the Catholic church, and the Tibetan children's video's tour of the Buddhist shrine, and the extended sequence demonstrating Tibetan dialectics, show the children's attempts to communicate across difference, with explanations and demonstrations. And, as this article's opening quote suggests, the Canadian student (R.) wasn't sure if the Tibetan students knew about the Jonas Brothers, while the Tibetan student in the video (M.) assumed this knowledge of his Canadian counterparts. This simple example implies a general understanding of the difference between the global and the local, in which children engage with their own place within the global cultural landscape.

\section{Pedagogical Implications}

Although the videomaking project reported on here was exploratory, our fieldbased observations of children's video production and student-teacher reports on the process have led us to consider if pedagogical interventions of various sorts, at various times in pre-production, production, and post-production, may enhance videos' ability not only to express children's artistic, textual, and sociocultural understandings and their questions, but also to contribute even more fully to their L2 learning. In research we are now conducting, we are considering whether theoretical frameworks such as Actor Network Theory (Latour, 2005) and heuristic tools from visual anthropology (Rose, 2007) might be useful to our analysis as we systematically document the videomaking process. For now, we wish to make some observations on the basis of the experience we have and the videos we have described here.

We believe the potential for videomaking to acknowledge, celebrate students' artistic, textual, and sociocultural knowledge of multicultural and multilingual film, pop culture, visual, aural, and online media is promising. In addition, videomaking can 
provide a way for teachers to elicit children's out-of-school resources in the school environment, a place that has not previously considered these matters in much depth. Using new tools for representation and new modes of meaning-making while integrating unfamiliar content will require educators themselves to learn new language, new cultural practices, and make more explicit some of the tacit knowledge they (as well as the children) bring to videomaking. We believe that a possible way for this learning to happen is for educators and students to first enjoy and then describe how filmmakers elicit particular feelings in viewers, how they structure stories, how they use sound and visual clues to direct viewers' attention and so on. This kind of critical media analysis will need to be developmentally appropriate, of course, and will not be completed in a single "unit", but rather could be engaged in at the same time that children are producing their own videos. As well, students and teachers might examine the results of noncommercial, artistic video production online; both independently and together, educators and L2 learners can search for videos that encourage multilingual practices. Commencing with popular multimedia references, the screening of diverse stylistic and cultural examples of videos then could contribute greatly to students' abilities to determine which formal or narrative multimedia language they wish to engage in, and equally could allow students to discover ways to experiment with or to subvert these forms. In-class samples provide not only implicit expectation but also invite mimicry; their selection should therefore be intentional, and acknowledged as inevitably influencing the children's video products. And, if we are to assess video products in future, we will need to acknowledge the intertextuality of other video and multimedia texts, students' increasing exposure to these texts, their influence on the decisions made about video content and filming style.

It is interesting to us in this case that while the assignment was, "tell the children in the other site what your lives are like", children in both sites interpreted this to mean tours of their schools and communities, portrayal of learning activities, and a literal "telling" of their stories. A rewording of the assignment or asking students about what they were choosing to portray (e.g. "Is this what your lives are like?") during planning and shooting might have yielded somewhat different representations. The "what" of the video-its subject matter, themes, images, and sounds-are often amongst the first choices made by either teachers or students. As projects develop, both educators and students might need to consider narrative or artistic coherence and consistency, artistic choices in audio-visual representations, and the potential meanings resulting from these choices. The key question is probably, "Why?" For example, instructors might have asked "Why do you want to include the church in your video?" or "Why did you speak to the audience in Tibetan and English, and why in that order?" While these questions are potentially endless, for educators, carefully chosen "why" questions can serve to engage learners more fully in their process, and often reveal the implications of pedagogical choices as evidenced in students' resulting products.

Many advocates of multimodal activities with children and youth observe that one of the biggest benefits of such activities are the changes in pedagogy these media demand, toward more "collegial" teaching. We agree that this is a potential pedagogical style that may be used in videomaking, but as we have observed in these and other cases, sometimes the adult appears to be the more powerful colleague. In our experience "student" video projects are sometimes hypermediated (Gutiérrez, Stone, \& Larson, 1999) by adults, particularly when adults are new to the technology and uncertain about 
children's capabilities to actually make video. Logistical issues of engaging a large number of students when only one camera is available (or computer with editing software), could also be reasons for this hypermediation. As Gutiérrez, Stone, and Larson (1999) suggest, such hypermediation is often in service of educator goals (in the case of videomaking: completion, order, and equity of access to the equipment) and it reduces student management of collaboration and also perhaps compromises their creative decisions. However, hypermediation is not inevitable, as several observers report more promising results in other cases (Chávez \& Soep, 2005; Rogers \& Scholfield, 2005). Such observers point out that one of the most important ways for collaborative multimodal production is for teachers to be comfortable with allowing students, often more "tech-savvy" than their teachers, to take leadership roles in problem solving, in accepting and working through struggles, group conflicts, and in fostering investment and resolve in themselves and their classmates. In the course of Pacific Cinémathèque's work with student video production, Elizabeth notes it is a common occurrence that previously identified "shy," "quiet," or "difficult" students discover their own leadership, technical, or problem solving skills while engaging with challenging situations.

Most teachers express the difficulty of knowing when teacher scaffolding, or student autonomy is most helpful to student learning. ${ }^{\mathrm{v}}$ It may be that the collegial pedagogy model is appropriate in some aspects of videomaking, with other aspects requiring more adult direction. Working within film set terminology, the teacher's role may be that of an Assistant Director, enforcing the creation of a carefully laid out storyboard/shot list and script, and then facilitating the realization of that plan. This collaborative approach might encourage students to explore their relationships to video production equipment and technology in terms of capability rather than limitation. Educators might frame the project as an opportunity for students to achieve their video's highest potential under their specific circumstances. The success of various young artists and filmmakers (whose work is often searchable and viewable online, for free) illustrates the capacity to create meaningful, artistic work under similarly restrictive technical and fiscal conditions. These videos can provide ideas for content, approach, and visual forms that may encourage creativity and allow students the ability to develop multimodal literacy practices.

In developing videomaking methods and accompanying assessment strategies, educators might consider how video, as both a form and an educational process, encourages students to ask higher-level critical thinking and compositional questions, and how their pedagogy directly influences that process. Assessment of these texts is rare now, and principled means of assessment will provide educators with challenges. Much more research is needed into effective assessment strategies.

Incorporating technical, logistical, and modal concerns, educators' methods have the potential to enhance and enrich students' engagement with multimedia texts in an educational context. Educator management of the logistical elements of production process also plays a significant role in student video productions. Initial project assignments (whether given in written and/or verbal form), the dynamic active-passive role in guiding the students and the project's content, scheduling and allotted time, the stated (and potentially enforced) project length, and allocated project resources (i.e., support in securing shooting locations, travel, props or costumes) all greatly influence student engagement with the project's process and product. 


\section{Conclusion}

The literacy challenges L2 learners face are well documented and daunting. However, their print literacy challenges are only part of the issue; like all citizens, their participation in the new literacies will be essential. We have been interested in videomaking with such learners as a multimodal literacy practice that might offer them opportunities for meaning making that extend beyond their present L2 capabilities. We have engaged in several videomaking projects with L2 learners, and in this paper, we describe three videos produced by L2 learners in different parts of the world. The videos have alerted us to aspects of this particular modality and how it is taught that might stimulate rich conversations among the child videomakers, researchers, and teachers.

We have said little so far about the possibilities for social networking that this project might have engendered, had there been follow-up to the children's video exchange. Hull, Stornaiuolo, and Sahni (2010) describe a project that used an Internet site to facilitate teenage girls in India representing themselves to themselves and to other youth in South Africa and the United States. These researchers demonstrate several examples of "small moments of intercultural exchange" (p. 349) that occurred in the project, which they term " "everyday cosmopolitanism', ... a hospitable semiotic sensibility, a habit of mind" (p. 350). We intend in future research to be alert to possibilities to engage L2 learners in this kind of cosmopolitanism, not only in global exchanges (where one might be bemused to learn about the worldwide appeal of the Jonas Brothers) but also in the kinds of local diversity they encounter in their homes and communities. Students' initial, active attempts at self-situation within a global cultural, multimedia framework offer exciting potential in the development of cosmopolitanism and transliteracies as described by Hull and Stornaiuolo (2010): "a starting place for including conceptions of local and global citizenship within its curricular and pedagogical purview, such as new spaces for building communities, including digital ones, and new kinds of civic engagements within those communities, ones that foreground communication and literate arts" (p. 86).

We believe that videomaking engages L2 learners in higher-level literacy considerations like awareness of audience, sequencing, and rhetoric, and that it can lead to activities of critical reflection and agentive self and collective expression. We are at beginning stages in substantiating these claims, but they underlie our interest in this multimodal means of meaning-making, and we hope others will investigate the affordances and constraints of this technology.

\section{References}

Ajayi, L. (2008). Meaning-making, multimodal representation, and transformative pedagogy: An exploration of meaning construction instructional practices in an ESL high school classroom. Journal of Language, Identity and Education 7(3 \& 4), 206-229.

Ajayi, L. (2009). English as a second language learners' exploration of multimodal texts in a junior high school. Journal of Adolescent and Adult Literacy 52(7), 585-595.

Appadurai, A. (1996). Modernity at large: Cultural dimensions of globalization. Minneapolis, MN: University of Minnesota.

August, D., \& Shanahan, T. (Eds.) (2006). Developing literacy in second-language 
learners. Mahwah, NJ: Lawrence Erlbaum Associates.

Australia Council for Educational Research (1997). Mapping literacy achievement. Results of the 1996 National School English Literacy Survey, ACER, Camberwell.

Barton, D., \& Hamilton, M. (1998). Local literacies: Reading and writing in one community. London, UK: Routledge.

Baudry, J. (1986). Ideological effects of the basic cinematographic apparatus. In P. Rosen (Ed.), Narrative, apparatus, ideology (pp. 286-298). New York, NY: Columbia University Press.

Bazin, A. (1967). What is cinema? Berkeley, CA: University of California Press.

Bordwell, D. (1986). Classical Hollywood cinema: Narrational principles and procedures. In p. Rosen (Ed.), Narrative, Apparatus, Ideology (pp. 17-34). New York, NY: Columbia University Press.

Bourne, J. (2007). Focus on literacy: ELT and educational attainment in England. In J. Cummins \& C. Davison (Eds.), International handbook of English language teaching (pp. 199-210). New York, NY: Springer.

Brass, J.J. (2008). Local knowledge and digital movie composing in an after-school literacy program. Journal of Adolescent and Adult Literacy, 51(6), 478-484.

Carrington, V., \& Marsh, J. (2005). Digital childhoods and youth: New texts, new literacies. Discourse: Studies in the Cultural Politics of Education, 26(3), 279-285.

Carrasquillo, A., Kucer, S., \& Abrams, R. (2004). Beyond the beginnings: Literacy interventions for upper elementary English language learners. Clevedon, UK: Multilingual Matters.

Casetti, F. (1996). Inside the gaze: The fiction film and its spectator. Bloomington, IN: Indiana University Press.

Chávez, V., \& Soep, E. (2005). Youth radio and the pedagogy of collegiality. Harvard Educational Review, 75(4), 409-434.

Coiro, J., Knobel, M., Lankshear, C., \& Leu, D.J. (Eds.), (2008). Handbook of research on new literacies. New York, NY: Lawrence Erlbaum.

Cope, B., \& Kalantzis, M. (Eds.) (2000). Multiliteracies: Literacy learning and the design of social futures. London, UK: Routledge.

Cummins, J. (2009). Literacy and English-language learners: A shifting landscape for students, teachers, researchers, and policy makers. Educational Researcher, 38(5), 382-385.

Cummins, J., \& Early, M. (Eds.). (2011). Identity texts: The collaborative creation of power in multilingual schools. Stoke on Trent, UK: Trentham Books.

Dagenais, D. (in press) Littératie multimodales et perspectives critiques. Les cahiers de l'Acedle.

Dagenais, D. (2008). Pratiques langagières des enfants de familles immigrantes à la maison et à l'école. Revue des sciences de l'éducation, 34(2), 351-376.

Dagenais, D., \& Moore, D. (2008). Représentations des littératies plurilingues, de l'immersion en français et des dynamiques identitaires chez des parents en chinois. Revue canadienne des langues vivantes, 65(1), 11-31.

Debruin-Parecki, A., \& Klein, H. A. (2003). Stvaranje Prijatelja/Making friends: Multimodal literacy activities as bridges to intercultural friendship and understanding in a cross-cultural collaborative literacy project. Journal of Adolescent \& Adult Literacy, 46(6), 506-513. 
Dyson, A. (1997). Writing superheroes: Contemporary childhood, popular culture and classrooms literacy. New York, NY: Teachers College Press.

Early, M., \& Marshall, S. (2008). Adolescent ESL students' interpretation and appreciation of literary texts: A case study of multimodality. The Canadian Modern Language Review/La Revue canadienne des langues vivantes, 64(3), 377-397.

Edutopia (2010).Welcome to the digital generation. Retrieved August 9, 2010, from http://www.edutopia.org/digital-generation-project-overview-video.

Edwards, R., Ivaniç R., \& Mannion, G. (2009). The scrumpled geographies of literacies for learning. Discourse: Studies in the cultural politics of education 30(4), 483-499.

Fernandez, M. (1999). Postcolonial media theory. Art Journal 58(3), 58-73.

Gee, J. P. (2004). Situated language and learning: A critique of traditional schooling. New York, NY: Routledge.

Grayson, J.P. (2008). The experiences and outcomes of domestic and international students at four Canadian universities. Higher Education Research \& Development, 27(3), 215-230.

Gromik, N. (2009). Meaningful tasks with video in the ESOL classroom. In E. HansonSmith \& S. Rilling (Eds.), Learning Languages through Technology. Alexandria, VA: Teachers of English to Speakers of Other Languages, Inc.

Gunderson, L. (2007). English-only instruction and immigrant students in secondary school: A critical examination. New York, NY: Lawrence Erlbaum.

Gutiérrez, K. (2008) Developing a sociocritical literacy in the third space. Reading Research Quarterly 43 (2), 148-164.

Gutiérrez, K., Zepeda, M., \& Castro, D.C. (2010). Advancing early literacy learning for all children: Implications of the NELP Report for dual-language learners. Educational Researcher 39(4), 334-339.

Gutiérrez, K., Stone, L., \& Larson, J. (1995) Hypermediating in the urban classroom: When scaffolding becomes sabotage in narrative activity. In C.D. Baker, J. CookGumperz, \& A. Luke (Eds.), Literacy and power. Oxford, UK: Blackwell.

Hague, C., \& Williamson, B. (2009). Digital participation, digital literacy, and school subjects: A review of the policies, literature and evidence. Retrieved September 7, 2009, from http://www.futurelab.org.uk/resources/digital-participation-digitalliteracy-and-school-subjects-literature-review

Hicks, A., \& Petrov, V. (2006). Auteur discourse and the cultural consecration of American films. Poetics 34(2006), 180-203.

Hanson-Smith, E. (2007). Classroom practice: Tasks for collaborative learning. In J. Egbert \& E. Hanson-Smith (Eds.) CALL environments: Research practice and critical issues (2nd ed.). Alexandria, VA: Teachers of English to Speakers of Other Languages, Inc.

Hawkins, M. (2004). Researching English language and literacy development in schools. Educational Researcher, 33(3), 14-25.

Hawkins, M. (2005). Becoming a student: Identity work and academic literacies in early schooling. TESOL Quarterly, 39(1), 59-82.

Heath, S. B. (1983). Ways with words: Language, life and work in communities and classrooms. Cambridge, UK: Cambridge University Press.

Heath, S. B., \& McLaughlin, M. W. (Eds.) (1993). Identity and inner-city youth. New York, NY: Teachers College Press. 
Hofer, M., \& Owings-Swan, K. (2005). Digital moviemaking:The harmonization of technology, pedagogy and content. International Journal of Technology in Teaching and Learning 1(2), 102-110.

Holland, D., Skinner, D., Lachiotte, W., \& Cain, C. (2001). Identity and agency in cultural worlds. Cambridge, MA: Harvard University Press.

Hull, G. and Schultz, K. (2002). School's out! Bridging out-of-school literacies with classroom practice. New York, NY: Teachers College Press.

Hull, G., \& Nelson, M. E. (2005). Locating the semiotic power of multimodality. Written Communication, 22(2), 224-261.

Hull, G. (2007). Mobile texts and migrant audiences: Rethinking literacy in a new media age. Plenary presentation to annual conference of the National Reading Conference. Austin, TX.

Hull, G., Jury, M., \& Zacher, J. (2007) Possible selves: Literacy, identity and development in work, school and community. In A. Belzer (Ed.), Toward defining and improving adult basic education (pp. 299-333), New York, NY: Lawrence Erlbaum.

Hull, G., \& Stornaiuolo, A. (2010). Literate arts in a global world: Reframing social networking as cosmopolitan practice. Journal of Adolescent and Adult Literacy, 54(2), 84-96.

Hull, G., Stornaiuolo, A., \& Sahni, U. (2010).Cultural citizenship and cosmopolitan practice: Global youth communicate online. English Education, 42 (4), 331-367.

Kist, W. (2005). New literacies in action: Teaching and learning in multiple media. New York, NY: Teachers College Press.

Kress, G. (2000). Multimodality: Challenges to thinking about language. TESOL Quarterly, 34, 337-340.

Kress, G. (2003). Literacy in the new media age. London, UK: Routledge.

Latour, B. (2005). Reassembling the social: An introduction to Actor-Network-Theory. Oxford, UK: Oxford University Press.

Levy, M., and Kennedy, C. (2004). A task-cycling pedagogy using audio-conferencing and stimulated reflection for foreign language learning. Language Learning \& Technology, 8(2), 50-68.

Li, J. (2010). A project-based approach to vocabulary acquisition: Filmmaking with ESL students. Canadian Association of Applied Linguistics meetings, Montréal, PQ.

Lopéz-Gopar, M. (2007). Beyond the alienating alphabetic literacy; Multiliteracies in indigenous education in Mexico. Diaspora, Indigenous and Minority Education l(3), 159-174.

Lotherington, H. (2007). From literacy to multiliteracies in ELT. In J. Cummins \& C. Davison (Eds.), International handbook of English language teaching (pp. 891905). NewYork, NY: Springer.

Lotherington, H. (2009). Glocalization, representation and literacy education. E-Learning and Digital Media, 6(3), 274.

Luke, C. (2002). Re-crafting media and ICT literacies. In D. Alvermann (Ed.), Adolescents and literacies in a digital world (pp. 132-146). New York, NY: Peter Lang.

Marsh, J. (2006). Global/local/public, private: Young children's engagement in digital literacy practices in the home. In K. Pahl \& J. Rowsell (Eds.), Travel notes from the 
New Literacy Studies: Instances of practice (pp. 19-38). Clevedon, UK: Multilingual Matters.

Marshall, E., \& Toohey, K. (2010). Representing family: Community funds of knowledge, bilingualism and multimodality. Harvard Educational Review, 80 (2), 221-241.

McCabe, (1986). Theory and film: Principles of realism and pleasure. In P. Rosen(Ed.) Narrative, apparatus, ideology (pp. 179-197). New York, NY: Columbia University Press.

Metz, C. (1977). The imaginary signifier: Psychoanalysis and the cinema. Bloomington, IN: Indiana University Press.

Mills, K.A. (2010a). Filming in progress: New spaces for multimodal designing. Linguistics and Education, 21, 14-28

Mills, K. A. (2010b). A review of the 'digital turn' in the New Literacy Studies. Review of Educational Research, 80(2), 246-271.

Nair, K. (2010). Aura, Auteurism and The Key to Reserva. Wide Screen 1(2), 1-20.

Pahl, K., \& Rowsell, J. (Eds.). (2006). Introduction. In K. Pahl \& J. Rowsell (Eds.), Travel notes from the New Literacy Studies: Instances of practice (pp.1-15). Clevedon, UK: Multilingual Matters.

Portes, A., \& Rumbaut, R. G. (2001). Legacies: The story of the immigrant second generation. Berkeley, CA: University of California Press.

Poyntz, S. (2006). Independent media, youth agency and the promise of media education. Canadian Journal of Education 29(1), 154-175.

Poyntz, S. (2009). "On behalf of a shared world": Arendtian politics in a culture of youth media participation. Review of Education, Pedagogy and Cultural Studies,31(4), 365-386.

Rhodes, J. A., \& Robnolt, V.J. (2009). Digital literacies in the classroom. In L. Christenbury, R. Bomer, \& P. Smagorinsky, (Eds.), Handbook of adolescent literacy research (pp. 153-169). New York, NY: The Guilford Press.

Rogers, T., Winters, K., LaMonde, A.M. and Perry, M. (2010). From image to ideology: Analyzing shifting identity positions of marginalized youth across the cultural sites of video production. Pedagogies: An International Journal, 5(4), 298-312.

Rogers, T. (2009). Theorizing media productions as complex literacy performances among youth in and out of schools. In D.L. Pullen \& D. Cole (Eds.), Multiliteracies and technology enhanced education: Social practice and the global classroom (). Philadelphia, PA: IGI Publications.

Rogers, T., \& Schofield, A. (2005). Things thicker than words: Portraits of youth multiple literacies in an alternative secondary program. In J. Anderson, M. Kendrick, T. Rogers, \& S. Smythe (Eds.) Portraits of literacy across families, schools and communities: Intersections and tensions (pp. 205-220). New York, NY: Lawrence Erlbaum.

Rose, G. (2007). Visual methodologies : An introduction to the interpretation of visual materials(2nd ed.). London, UK: Sage.

Rowsell, J. (2006). Literacy revisited. Orbit, 36(1), 1.

Sanford, K., \& Madill, L. (2008). Teachers and students learning through videogame design. In R. Ferdig(Ed.), Handbook of research on effective electronic gaming in education (pp. 345-357). New York, NY: Information Science Reference. 
Saper, C. (1991). A nervous theory: The troubling gaze of psychoanalysis in media studies. Diacritics, 21(4), 32-52.

Sarris, A. (1976). Towards a theory of film history. In B. Nichols (Ed.), Movies and methods: An anthology (pp. 237-250). Berkeley, CA: University of California Press.

Skinner, E., \& Hagood, M. (2008). Developing literate identities with English language learners through digital storytelling. The Reading Matrix, 8(2), 12-38.

Smythe, S. and Toohey, K. (2009a). Investigating sociohistorical contexts and practices through a community scan: A Canadian Punjabi Sikh example. Language and Education 21 (1), 37-57.

Smythe, S. and Toohey, K. (2009b). Bringing home and community to school:

Institutional constraints and pedagogic possibilities. In J. Miller, A. Kostogriz and M. Gearon (Eds.), Culturally and linguistically diverse classrooms: New dilemmas for teachers (pp. 271-290). Bristol: Multilingual Matters.

Stein, P. (2004). Representation, rights and resources: Multimodal pedagogies in the language and literacy classroom. In B. Norton \& K. Toohey (Eds.), Critical pedagogies and language learning (pp. 95-115). Cambridge, UK: Cambridge University Press.

Street, B. (1984). Literacy in theory and practice. Cambridge, UK: Cambridge University Press.

Street, B. (1995). Social literacies: Critical approaches to literacy, development, ethnography and education. Boston, MA: Addison-Wesley.

Street, B. (1998). New literacies in theory and practice: What are the implications for language in education? Linguistics and Education, 10(1), 1-24.

Strickland, D., \& Alvermann, D. (2004). Bridging the literacy achievement gap: Grades 4-12. New York, NY: Teachers College Press.

Toohey, K. and Derwing, T. (2008). ESL students and secondary school achievement in BC. Alberta Journal of Educational Research 54(2), 178-193.

Toohey, K., \& Dagenais, D. (in press). Movie making with second language learners. In J.Li (Ed.), Video digital media. Alexandria, VA: TESOL Publications.

Vallet, L-A, et Caille, J-P. (2000). La scolarité des enfants d'immigrés. In A. Van Zanten (Ed.), l'École : l'état des saviors (pp. 293-301). Paris, France: La Découverte.

Ware, P. (2008). Language learners and multimodal literacy in and after school. Pedagogies: An International Journal, 3(1), 37-51.

Willis, A.I., \& Harris, V.J. (2000). Political acts: Literacy learning and teaching. Reading Research Quarterly, 35(1), 72-89.

Wollen, P. (1970). Signs and meaning in the cinema. London, UK: Thames and Hudson Limited, British Film Institute.

Author Biographies

Kelleen Toohey is Professor in the Faculty of Education at Simon Fraser University. Her recent research has focused on multimodal literacy instruction for learners of English as an additional language. 
Diane Dagenais is Professor in the Faculty of Education at Simon Fraser University. Her research focuses on multilingual learners and her recent work explores multimodal forms of expression using tools such as videomaking in educational contexts.

Elizabeth Schulze is Education Manager for Pacific Cinémathèque and has worked with amny children and youth making videos. She recently completed an M.A. in Communications at Simon Fraser University.

\section{Endnotes}

i The term "second languages" is often inaccurate when describing children learning a school language, as many such children use more than two languages and/or varieties of languages in their daily lives. In this paper, we continue to use the conventional term, but recognize its limitations.

${ }^{i i}$ Some of the data presented in this paper are also discussed in:

Toohey, K. \& Dagenais, D. (in press). Movie making with second language learners. In J. Li (Ed.), Video digital media. Alexandria, VA: TESOL Publications.

Dagenais, D. (in press). Littératie multimodales et perspectives critiques. Les cahiers de L'Acedle.

iii The Golden Temple in Amritsar is of special significance to these children and their families, as it is Sikhism's holiest shrine.

iv The ellipsis in this transcript indicates parts of the child's speech that were incomprehensible to us.

${ }^{v}$ For example, in work with student video productions at Pacific Cinémathèque, a "No Bloopers" rule in all creative work has been instituted. Over many years, it was discovered that in many cases students would spend either more class time in the creation of the "blooper reel" than in the actual video, or would abandon challenging creative problems to instead focus on an "easy" and fun activity in the blooper reel. Depending on the group's engagement and commitment to their film's idea, this occurred as early as the production process, when they had not completed filming their required shots for the project's planned components. The form of the blooper reel, mimicking feature films' end sequences, is easy to create, virtually guarantees audience laughter, and thus facilitates the process of student disengagement from the more difficult but ultimately rewarding tasks of considering deeper audience engagement, developing coherent narrative structure, and engaging in the realization of conceptual ideas in concrete visual and aural representation. 